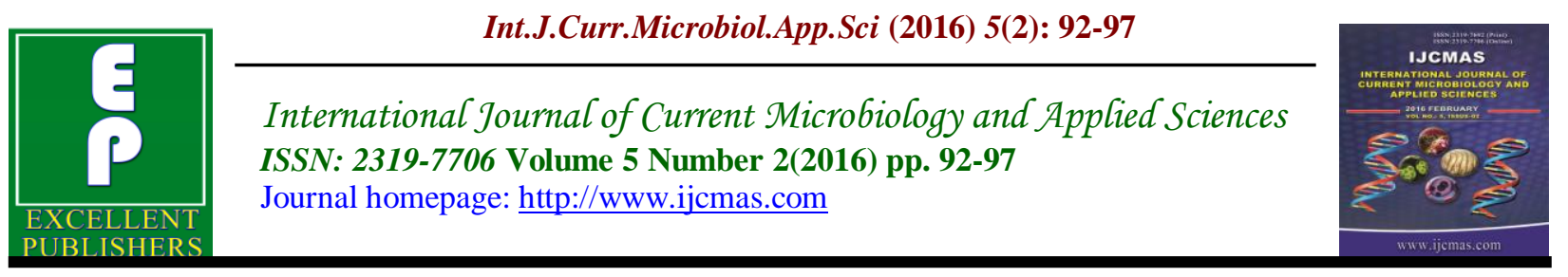

Original Research Article

doi: http://dx.doi.org/10.20546/ijcmas.2016.502.010

\title{
Primary Screening of Actinomycetes in prospects with Biosurfactant Production from Animal fat waste
}

\author{
S.B. Patil ${ }^{1 *}$, Y.A. Patil Sawant ${ }^{2}$, L.H. Kamble ${ }^{2}$ and C.J. Raorane ${ }^{1}$ \\ ${ }^{1}$ Department of Microbiology, Kankavli College, Kankavli, Dist: Sindhudurg Maharashtra, India \\ ${ }^{2}$ School of Life sciences, S.R.T.M University, Nanded, India \\ *Corresponding author
}

\section{A B S T R A C T}

Keywords

Bioemulsifier,

Biosurfectant

Actinomycetes,

Animal fat waste,

drop collapse

method

Article Info

Accepted:

09 Januaryr 2016

Available Online:

10, February 2016
Emulsifier is a chemical compounds having water loving hydrophilic head and an oil loving hydrophobic tail which help in uptake of water insoluble liquids by reduction of surface tension. Emulsifier potentially useful in food, Agriculture, Pharmaceutical, Petrochemical industries. Chemical Emulsifier cause harm to environment so need the alternatives Bioemulsifier are the emulsifier naturally produced from the microorganisms like Bacillus spp, Pseudomonas spp. and Candida spp. In the present study Bioemulsifier was produced from the Actinomycetes which is isolated from river sludge deposited along with the animal fat waste. In this study found that $\mathrm{A}_{6}$ Isolate shows best yield of the emulsifier and it may possible to use for commercial production of the Bioemulsifier. Their Phylogenetic affinity of this isolates was analyze with $16 \mathrm{~S}$ rRNA sequencing followed with Blast.

\section{Introduction}

Bacteria produce a wide range of extracellular products with many properties and applications. Biosurfactants are one such extracellular amphiphilic compounds produced by bacteria, yeast and fungi, especially when they are grown on hydrophobic substrates. The potential use of emulsifier in different areas such as the food industry, agriculture, pharmaceutical, oil industry, petro chemistry, paper \& pulp industry makes it a versatile product (Fracchia and Cavallo, 2012).
Earlier the emulsifiers are produced chemically, which was wealthy \& causing environmental pollution so that there was need to replace them by only other compound which is alternative for this chemical emulsifier, can be produced within low budget and does not interfere with environment (Colin et al., 2013).

Apart from their potential applications in bioremediation, bio surfactants compounds have wide prospects in medicine as 
antimicrobials, anti-adhesives inhibiting bio film formation, as anti-adhesives, biological coatings, fibrin-clot lysing agents etc (Fracchia \& Cavallo, 2012; Satpute et al., 2010). Traditionally the bioemulsifier have been produced by using Bacillus sp., Candida sp. and Pseudomonas sp. and their studies are well documented (Chandran, 2010; Ghribi et al., 2012; Padmapriya \& Suganthi, 2013; Tambekar \& Gadakh, 2013; Vandana \& Peter, 2014). However only a few reports are available in comparison that describe bio surfactants or bioemulsifier production from actinomycetes (Khopade et al., 2012). The problem with commercialization of the bioemulsifier is their production cost and the research on the use of cheap renewable substrate for the production has only concentrated on agricultural waste and very little on the animal fat waste (Banatet al., 2014) Also, the studies on actinomycetes in India are in preliminary stages only (Velho-Pereira \& Kamat, 2013) and worldwide the studies on aquatic actinomycetes are neglected (Ningthoujam, et al., 2009; Rifaat, 2003; Takizawa et al., 1993). Thus this study was under taken to assess the bioemulsifier production of two actinomycetes isolates from Godavari river sediments using animal fat waste as a substrate.

\section{Materials and Methods}

Sample Collection: for the isolation of the Actinomycetes sample was collected from the Gad, and Godavari river area from the river sediment and enrichment was carried out by Using Bushnell Haas agar enriched with $0.1 \%$ crude oil. Animal fat waste was collected from the local market, both samples are collected in aseptic bags and processed and used within $24 \mathrm{hrs}$.

Media Designing: Two sets of media were prepared, Media I ${ }^{\text {st }}$ (Peptone-0.5gm, NaCl-
$0.25 \mathrm{gm}$, Yeast extract $-0.15 \mathrm{gm}$, Fat $-0.5 \mathrm{gm}$, D/W-50ml) Media II ${ }^{\text {nd }}$ (L-Asparagine$0.025 \mathrm{gm}, \quad \mathrm{KH}_{2} \mathrm{PO}_{4}-0.025 \mathrm{gm}, \quad \mathrm{MgSO}_{4}-$ $0.01 \mathrm{gm}, \quad \mathrm{FeSO}_{4}-0.0005 \mathrm{gm}, \quad$ Fat $-0.5 \mathrm{gm}$, $\mathrm{D} / \mathrm{W}-50 \mathrm{ml}$ )

Fermentation Process: Firstly the designed media were divided into two flasks, i.e. $25 \mathrm{ml}$ in each and sterilized by autoclaving, further labeled as, Set I A, Set I B, Set II A, Set II B, Then the labeled media were inoculated by developed inoculums, of isolates i.e. A6, S15 In Set I A inoculated with inoculums of A6, Set II A was inoculated with inoculums of S15, Set I B inoculated with inoculums of A6, Set II B inoculated with inoculums S15. After inoculation the flasks were incubated on shaker incubator at $30^{\circ} \mathrm{C}$ for 7 days, on 120 RPM. After incubation period centrifugation of the fermented broth done at 3000 RPM for $15 \mathrm{~min}$. Then the supernatant were collected. After collection of supernatant, the collected supernatants were used for drop collapse method.

Drop Collapse Test: $2 \mu$ of respective oil was applied to the well regions of the 96well micro-plate lids and allowed to equilibrate for $24 \mathrm{~h}$. Five micro liters of the cell free culture broth was transferred to the oil coated regions and the drop size was observed 1 min later with the aid of a magnifying glass. A result was considered positive for biosurfactant production when the drop diameter was at least $1 \mathrm{~mm}$ larger than that produced by $\mathrm{S}_{15}$ (negative control). SDS (a chemical surfactant) solution prepared at $1 \mathrm{mg} / \mathrm{ml}$ concentration was used as a standard.

Emulsification Index: Emulsification activity was measured by using mixture of 1 $\mathrm{ml}$ culture supernatant along with the respective oil, $4 \mathrm{ml}$ water and $6 \mathrm{ml}$ respective oil vortex for $2 \mathrm{~min}$ and then 
placed for the emulsification after $48 \mathrm{hrs}$ emulsification index calculated by measuring the height of the emulsion layer and using formula $\mathrm{EI}=\mathrm{a} / \mathrm{bX100}$ (where $\mathrm{a}$, height of emulsion layer $b$, total height).

\section{Result and Discussion}

From the 15 samples was collected from the sampling site at October 2014 from which 6
Actinomycetes isolate was identified within them $\mathrm{A}_{6}$ shows maximum yield about $46.23 \%$ this strains may have the industrial prospects in concern with the biosurfactant production using animal waste as an substrate. Taxonomic affinity of isolate S15 and A6 as established through 16s rRNA searches against RDP Naive Bayesian rRNA Classifier Version 2.10 database and closest relative as identified through

Table.1 Observations for Drop Collapse Method and Emulsification Assay

\begin{tabular}{|c|c|c|c|c|c|c|}
\hline \multirow{2}{*}{ Sample } & \multicolumn{3}{|c|}{ Drop collapse method } & \multicolumn{3}{c|}{ Emulsification Index /ml } \\
\cline { 2 - 7 } & $\begin{array}{c}\text { Kerosene } \\
\text { oil }\end{array}$ & $\begin{array}{c}\text { Sunflower } \\
\text { oil }\end{array}$ & $\begin{array}{c}\text { Coconut } \\
\text { oil }\end{array}$ & $\begin{array}{c}\text { Kerosene } \\
\text { oil }\end{array}$ & $\begin{array}{c}\text { Sunflower } \\
\text { oil }\end{array}$ & $\begin{array}{c}\text { Coconut } \\
\text { oil }\end{array}$ \\
\hline SDS (+control) & +++ & +++ & +++ & 70.80 & 69.38 & 75.26 \\
\hline $\mathrm{S}_{15}$ (-ve control) & - & - & - & 00.10 & 00.21 & 00.21 \\
\hline $\mathrm{A}_{1}$ & - & - & - & - & - & - \\
\hline $\mathrm{A}_{2}$ & - & - & - & - & - & - \\
\hline $\mathrm{A}_{3}$ & ++ & + & - & 24.00 & 10.20 & - \\
\hline $\mathrm{A}_{4}$ & + & - & ++ & 12.10 & - & 24.12 \\
\hline $\mathrm{A}_{5}$ & ++ & - & - & 20.12 & 00.10 & 00.20 \\
\hline $\mathrm{A}_{6}$ & +++ & +++ & ++ & 45.33 & 46.23 & 42.12 \\
\hline
\end{tabular}

-:No activity, +: positive activity, ++:weak positive activity, +++: Good activity

Table.2 Taxonomic Affinity of Isolate S15 and A6 as Established Through 16s Rrn Searches against RDP Naive Bayesian rRNA Classifier Version 2.10 Database and Closest Relative as Identified Through GenBank using the Tool BLAST (blastn)

\begin{tabular}{|c|c|c|}
\hline Name of the Isolate & S 15 & A 6 \\
\hline Domain & Bacteria & Bacteria \\
\hline Phylum & Actinobacteria & Actinobacteria \\
\hline Class & Actinobacteria & Actinobacteria \\
\hline Subclass & Actinobacteridae & Actinobacteridae \\
\hline Order & Actinomycetales & Actinomycetales \\
\hline Suborder & Streptomycineae & Corynebacterineae \\
\hline Family & Streptomycetaceae & Nocardiaceae \\
\hline Genus & Streptomyces & Nocardia \\
\hline Closest relative & $\begin{array}{c}\text { Streptomyces cinereospinus } \text { strain } \\
173285 \text { 16S ribosomal RNA } \\
\text { gene, partial sequence }\end{array}$ & $\begin{array}{c}\text { Nocardia higoensis } \text { strain IFM } \\
\text { 10084 16S ribosomal RNA, } \\
\text { partial sequence }\end{array}$ \\
\hline Accession number & EU593556.1 & NR_028651.1 \\
\hline$\%$ similarity & $99 \%$ & $99 \%$ \\
\hline
\end{tabular}


Figure.1 Showed Neighbor- joining tree
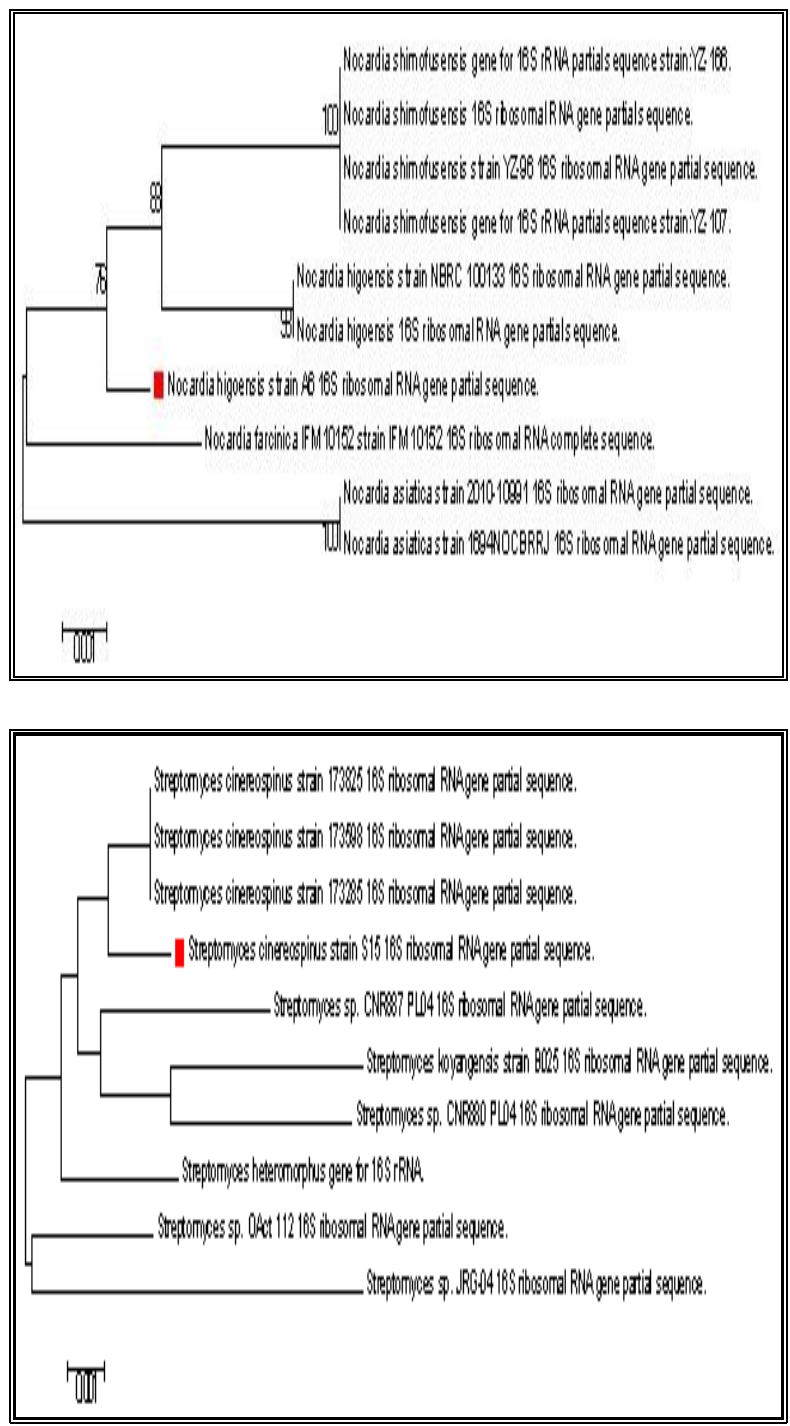

GenBank using the tool BLAST (blastn), to in search of the Phylogenetic position, lab isolate $\mathrm{S}_{15}$ belongs to Streptomycetaceae family and isolate $\mathrm{A}_{6}$ belongs to Nocardiaceae family

Neighbor- joining tree of closest relatives of S15 and A6 respectively identified in blastn search The evolutionary history was inferred using the Neighbor-Joining method (Saitou and Nei, 1987). The optimal tree with the sum of branch length $=0.03748104$ is shown in figure:no:01( $a$ and $b$ )
Figure.1 showed Neighbor- joining tree of closest relatives of S15 and A6 respectively identified in blastn search The evolutionary history was inferred using the NeighborJoining method (Saitou and Nei, 1987). The optimal tree with the sum of branch length $=$ 0.03748104 .

\section{References}

Banat, I. M., Satpute, S. K., Cameotra, S. S., Patil, R., \&Nyayanit, N. V. (2014). Cost effective technologies and renewable 
substrates for biosurfactants' production. Frontiers in Microbiology, 5: 697.

Chandran, P. (2010). Biosurfactant production and diesel oil degradation by yeast species trichosporon asahii isolated from petroleum hydrocarbon contaminated soil. International Journal of Engineering Science and Technology,2(12):6942-6953.

Colin, V. L., Pereira, C. E., Villegas, L. B., Amoroso, M. J., \& Abate, C. M. (2013). Production and partial characterization of bioemulsifier from a chromiumresistant actinobacteria. Chemosphere, 90(40) 1372-8.

Deepika, L., \& Kannabiran, K. (2010). Biosurfactant and Heavy Metal Resistance Activity of Streptomyces spp - Isolated from Saltpan Soil. British Journal of Pharmacology and Toxicology, 1(1): 33-39.

Gandhimathi, R., Seghal Kiran, G., Hema, T. A., Selvin,J., Rajeetha Raviji, T., \& Shanmughapriya, S. (2009). Production and characterization of lipopeptide biosurfactant by a sponge-associated marine actinomycetes Nocardiopsis alba MSA10. Bioprocess and Biosystems Engineering, 32(6):825-35.

Ghribi, D., Abdelkefi-Mesrati, L., Mnif, I., Kammoun, R., Ayadi, I., Saadaoui, I,Chaabouni-Ellouze, S. (2012). Investigation of antimicrobial activity and statistical optimization of Bacillus subtilis SPB1 biosurfactant production in solid-state fermentation.Journal of Biomedicine \& Biotechnology, 2012, 373682.

Hayder, N., Alaa, S., \& Abdulmalik, H. (2014).

Kalyani, A. L. T., Sireesha, N., Aditya, A., Shankar, G., \& T, P. (2014). Production Optimization of Rhamnolipid Biosurfactant by Streptomyces coelicoflavus ( NBRC 15399 T ) using
Plackett-Burman design. European Journal of Biotechnology and Bioscience, 1(5): 7-13.

Khopade, A., Biao, R., Liu, X., Mahadik, K., Zhang, L., \& Kokare, C. (2012). Production and stability studies of the biosurfactant isolated from marine Nocardiopsis sp . B4. Desalination, 285, 198-204.

Kokare, C. R., Kadam, S. S., Mahadik, K. R., \& Chopade, B. A. (2007). Studies on bioemulsifier production from marine Streptomyces sp . S1. Indian Journal of Biotechnology, 6(January): 78-84.

Maniyar, J. P., Doshi, D. V, Bhuyan, S. S., \& Mujumdar, S. S. (2011). Bioemulsifier production by Streptomyces sp. S22 isolated from garden soil. Indian Journal of Experimental Biology,49(4):2937.Retrieved frohttp ://www.ncbi.nlm.nih.gov/pubmed/2161 4894

Ningthoujam, D. S., Sanasam, S., \& Nimaichand, S. (2009). Screening of Actinomycete Isolates from Niche Habitats in Manipur for Antibiotic Activity. American Journal of Biochemistry and Biotechnology, 5(4):221-225.

Optimized Conditions for Bioemulsifier production by Local Streptomyces sp . SS 20 isolated from hydrocarbon contaminated soil. Romanian Biotechnological Letters, 19(1):89798993.

Padmapriya, B., \& Suganthi, S. (2013). Antimicrobial and Anti Adhesive Activity of Purified Biosurfactants Produced by Candida species, 14(10):1359-1369.

Padmapriya, B., \& Suganthi, S. (2013). Antimicrobial and Anti Adhesive Activity of Purified Biosurfactants Produced by Candida species, 14(10):1359-1369. 
Rifaat, H. M. (2003). The biodiversity of Actinomycetes in the River Nile exhibiting antifungal activity. Journal of Mediterranean Ecology, 4(3): 5-7.

Saitou, N., \& Nei, M. (1987). The Neighborjoining Method: A New Method for Reconstructing Phylogenetic Trees '. Molecular Biology and Evolution, 4(4): 406-425.

Satpute, S. K., Banpurkar, A. G., Dhakephalkar, P. K., Banat, I. M., \& Chopade, B. a. (2010). Methods for investigating biosurfactants and bioemulsifiers: a review. Critical Reviews in Biotechnology, 30(2):12744.

Takizawa, M., Colwell, R. R., \& Hill, R. T. (1993). Isolation and Diversity of Actinomycetes in the Chesapeake Bay. Applied and Environmental Microbiology, 59(4):997-1002.

Tambekar, D. H., \& Gadakh, P. V. (2013). Bioemulsifier production and molecular detection of pseudomonas spp . Isolated from hydrocarbon. International
Journal of Science, Environment, 2(3): 470-477.

Tamura, K., Nei, M., \& Kumar, S. (2004). Prospects for inferring very large phylogenies by using the neighborjoining method. Proceedings of the National Academy of Sciences of the United States of America,101(30): 11030-5.

Tamura, K., Stecher, G., Peterson, D., Filipski, A., Kumar, S., \& Arabia, S. (2013). MEGA6: Molecular Evolutionary Genetics Analysis version 6. 0. Molecular Biology and Evolution, 30: 2725-2729.

Vandana, P., \& Peter, J. K. (2014). Production, partial purification and characterization of biosurfactant produced by pseudomonas fluorescens. International Journal of Advanced Technology in Engineering and Science, 2(7): 258-264.

Velho-Pereira, S., \& Kamat, N. M. (2013). Actinobacteriological research in India. Indian Journal of Experimental Biology, 51(8): 573-96.

\section{How to cite this article:}

Patil, S.B., Y.A. Patil Sawant, L.H. Kamble and Raorane, C.J. 2016. Primary Screening of Actinomycetes in prospects with Biosurfactant Production from Animal fat waste. Int.J.Curr.Microbiol.App.Sci. 5(2): 92-97. doi: http://dx.doi.org/10.20546/ijcmas.2016.502.010 